\title{
さまよえる公立博物館 指定管理者導入の現状と問題点一
} 前沢和之

\section{はじめに}

文部科学省が実施した平成17年度社会教育調 査によると、全国には5,6140博物館があり、平 成16年度には総計 272,682 千人の入館者があっ た。また、平成16年度に日本博物館協会が行っ た総合調査では、1館当たりの収蔵資料数の平均 值は人文系資料 39,004 点 - 自然系資料 30,385 点 で、これ以外に多数の図書資料・映像資料など も保管されている。これらのデータから、博物 館は地域の人々にとって身近な文化施設である とともに、住民共有の財産である学術・芸術資 料、地域・環境資料のデータバンクの役割を果 たしているのが明らかである。

これらの約73\%は都道府県・市町村により設 置された公立博物館で、これがわが国の博物館 の中核を成す存在と見てよい。ところが今、こ の多くが先行きの見元難い闇の中をさまよう状 況に陥っているのである。旮をもたらした原 因の一つが指定管理者制度の導入であるが、こ の実情は直面した関係者以外にはほとんど知ら れていない。しかし、いつの間にか近くの博物 館が閉められたり、資料の閲覧や借用ができな くなったりする事態が目前にあるとしても過言 ではない。ここでは、この制度導入での暴走や 迷走を防ぐため、現状を明らかにするとともに、 取り組もべき問題点を示して広く世諭を喚起す るための一助としたい。

\section{1 指定管理者制度と公立博物館}

指定管理者制度は地方自治法の一部改正（平 成15年6月13日公布)により実施されたが、その 第244条の2に示される要点は次のことである。

(1)基本選択肢：直営または指定管理者制度 (2)指定管理者制度適用での条件設定：

ア 指定の手続き・管理の基準・業務の範囲 等を定める。

イ 期間を定める。

ウ 利用料金収受の可否。

(3)選択・選定の判断：地方公共団体＜首長・議 会>に委ねられている。

これは規制緩和や「官から民へ」政策の一環で あるが、この施行に際しての総務省自治行政局 通知 (平成15年7月17日付) には、選定基準とし て「住民の平等利用の確保」、「施設効用の最大 化」「管理経費の縮減」、管理を安定的に行う 物的・人的能力の保有」があげられている。ま た、博物館への適用については平成 15 年 12 月 1 日に文部科学省からその方針が明らかにされ、 各館の設置目的・地域の状況に応じた選択と指 定条件の設定が可能であることが示された（『博 物館研究』No.435所載「公立博物館に対する 指定管理者制度の考方方について」等を参照)。

以上のことから明らかなように、この制度導 入の選択や条件設定に当たっては、各博物館の 設置目的に対する設置者 (地方公共団体) の認識 と判断が決定的な役割を果たすのである。 


\section{2 博物館導入の現状}

平成18年6月に開催された第13回全国博物館 館長会議資料によると、指定管理者制度の導入 状況は表1のと抢りである。

回答館4790内、A：既に導入112館 $(23.4 \%) 、$

$\mathrm{B}+\mathrm{C}$ : 導入が決定 26 館 $(5.4 \%)$ で、 $\mathrm{A}+\mathrm{B}+$ Cの合計は138館（28.8\%）となっている。

これを導入前の管理形態と導入後の委託先で

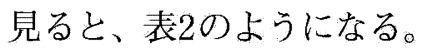

導入前は、財団：90館 $(80.4 \%) 、$ 直営：10
館 $(8.9 \%)$ 、導入後では、自治体の出資法人 公共団体：97館 $(86.6 \%)$ 、民間事業者・N P O6 館 $(5.4 \%)$ である。平成16年9月の調查で は、A：既に導入 $2.0 \% 、 B+C ：$ 導入が決定 $9.5 \% 、 \mathrm{~A}+\mathrm{B}+\mathrm{C}$ 合計は $11.5 \%$ であったのと 比較して、導入は急速に進んでいる。

ここで特徴的なのは、博物館全体の約 $24 \% を$ 占める管理委託制度適用館（導入前は「財団」 が該当）が突出していることである。これは地 方自治法附則の第1条及び第 2 条によって、平成 18年9月2日までに指定管理者制度への切り換え

表 1

\begin{tabular}{|c|c|c|c|c|c|c|c|c|c|c|c|c|c|}
\hline \multirow{3}{*}{$\begin{array}{l}\text { 設 } \\
\text { 置 } \\
\text { 者 }\end{array}$} & \multirow{3}{*}{$\begin{array}{l}\text { 依 } \\
\text { 頼 } \\
\text { 館 }\end{array}$} & \multirow{3}{*}{$\begin{array}{l}\text { 回 } \\
\text { 答 } \\
\text { 館 }\end{array}$} & \multicolumn{5}{|c|}{ 導入前· 現在 } & \multirow{3}{*}{$\begin{array}{l}A \\
\text { 既 } \\
\text { L } \\
\text { 導 } \\
\lambda \\
\text { L } \\
\text { C } \\
\text { え } \\
\text { る }\end{array}$} & \multirow{3}{*}{$\begin{array}{l}\text { B } \\
\text { 平 } \\
\text { 盛 } \\
\text { 年 } \\
\text { 号 } \\
5 \\
\text { 導 } \\
\text { 予 } \\
\text { 定 }\end{array}$} & \multirow{3}{*}{ 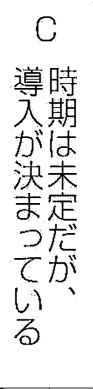 } & \multirow{3}{*}{ 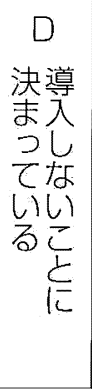 } & \multirow{3}{*}{$\begin{array}{l}E \\
わ \\
か \\
5 \\
\text { な } \\
\text { w }\end{array}$} & \multirow{3}{*}{$\begin{array}{l}F \\
\text { そ } \\
\text { 他 }\end{array}$} \\
\hline & & & \multirow{2}{*}{$\begin{array}{l}\text { 直 } \\
\text { 営 }\end{array}$} & \multicolumn{2}{|c|}{ 財団委託 } & \multirow{2}{*}{$\begin{array}{l}\text { そ } \\
\text { 他 }\end{array}$} & \multirow{2}{*}{$\begin{array}{l}\text { 記 } \\
\text { 入 } \\
\text { な } \\
\text { し }\end{array}$} & & & & & & \\
\hline & & & & 全 & $\begin{array}{l}\text { そ } \\
\text { 他 }\end{array}$ & & & & & & & & \\
\hline 県立 & 172 & 136 & 66 & 33 & 2 & 4 & 31 & 43 & 2 & 2 & 27 & 56 & 6 \\
\hline 指定都市 & 65 & 46 & 18 & 16 & 3 & 0 & 9 & 22 & 1 & 0 & 6 & 16 & 1 \\
\hline 市・ 区立 & 380 & 264 & 154 & 36 & 6 & 5 & 63 & 46 & 10 & 8 & 66 & 128 & 6 \\
\hline 町村立 & 92 & 33 & 18 & 1 & 0 & 14 & 0 & 1 & 1 & 2 & 9 & 20 & 0 \\
\hline 合計 & 709 & 479 & 256 & 86 & 11 & 23 & 103 & 112 & 14 & 12 & 108 & 220 & 13 \\
\hline
\end{tabular}

表2

\begin{tabular}{|l|r|}
\hline 導入前の管理形態 & 館数 \\
\hline \hline 直営 & 10 \\
\hline 財団 & 90 \\
\hline その他 & 8 \\
\hline 無回答 & 4 \\
\hline 合計 & 112 \\
\hline
\end{tabular}

\begin{tabular}{|l|r|}
\hline 導入後の委託先 & 館数 \\
\hline \hline 自治体の出資法人·公共団体 & 97 \\
\hline 民間事業者·NPO & 6 \\
\hline その他 & 6 \\
\hline 無回答 & 3 \\
\hline 合計 & 112 \\
\hline
\end{tabular}


が定められたことによる。つまり、公立博物館 への指定管理者制度導入の第1段階（平成15～ 18年) は、基本選択の余地のない既存の管理委 託制度適用館を中心に進められたのである。そ の一方、新設館での導入も進められ平成17年11 月3日に開館した長崎歷史文化博物館がその典 型例として喧伝されている。しかし、一見する と同じようでも、両者では前提条件が大きく異 なっていることに注意しなくてはならない。つ まり、既存館では募集に際して設置者はこれま での実績を超える業務内容と経費縮減を求め、 応募者注他社と競争するためにもこれを上回る 水準のものを提示することが必定である。これ に対して新設館では、設置者はこの制度を前提 とした管理基準・業務範团や予算額を設定する ため、応募者はそれに即した条件を整えるのが 比較的容易である。また、それらの設定に無理 があると見れば応募しなくてもよいのである。 この相違を無視した主張や説明に接することが 多いが、これは制度運用の暴走と博物館界の混 乱を助長する原因となるもので、慎むべきこと を強調して扰きたい。

表2では、導入後の委託先として「自治体の出 資法人・公共団体」が $86.6 \%$ を占めていること にも注目される。ほとんどの場合において、導 入前の「財団」が艺のまま指定管理者に選定され たことを示しているのである。もちろん、公募 競争の結果てれまでの運営団体が選ばれた場合 も少なくない。しかし、管理委託制度からの転 換により既存の財団の解散や職員の解雇等の問 題が発生することへの懸念、専門的業務の継続 と住民共有の財産である収蔵資料の継承への対

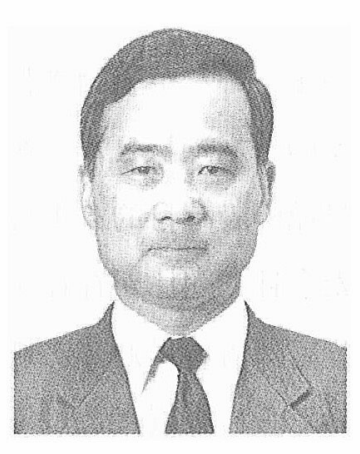

PROAII

前沢和之

(まえざわ かずゆき 1946年生)

日本学術会議特任連携会員、横浜市 歴史博物館課長、日本博物館協会常 務委員

専門：日本古代史、歴史考古学、博 物館学

処について、設置者側の判断がまとまらなかっ た結果、当座の $2 \sim 3$ 年間はこれらを指定管理者 に選定し、導入検討のための猶予期間を設けた 事例も少なからず見受けられた。このことを指 して「民間への開放度が低い」と批判する向き も㐫が、もしろ制度についての検討がされな いまま導入が押し進められたことの問題点を、 如実に示すものと受け止めるべきであうう。

\section{3 博物館導入の問題点}

第1段階では、設置者および応募者の双方で、 この制度に関する認識の不十分さに起因する戸 惑いと対処の遅れが目立った。その中で、管理 委託制度の特色とされた「職員が長期にわたつ て專門業務に従事でき、質の高いサービスを提 供できる」運営方式が解体されたことに言及す る論説は見られなかった。しかし、これの是非 は前節で述べた猶予期間を終えるまで、また、2 巡目の指定管理者選定を迎えるまでにきちんと 検証すべき問題点であることを指摘しておきた い。

現在、第2段階（平成18～20年頃）として直営 館への導入が進められているが、ここでは設置 者の財政面と運営の効率性を重視した判断が、 
これまで以上に強まることが予測される。先ず は、直営か導入かの基本選択となるが、ここで の決定的な要件は館の設置目的を実現できる能 力と実績をもった会社や団体が存在するかであ る。これの確認や応募者の見通しが無いまま導 入に踏み切るとしたら、設置者としての責任放 棄と言わざるを得ない。また、直営からの転換 では運営のほとんどの面にわたって断絶と混乱 が生じ、博物館としての機能を抆失してしまう 懸念が強い。それを最小限にとどめる上で肝腎 なのは、管理の基準・業務の範囲の条件設定に 当たって、これまでの実績を踏まえ現在の館職 員や実務経験者の意見を十分に聞くことである。 この第 2 段階は指定管理者導入の本番と言える ものであるが、公共施設のあり方や地域との関 わりの面では、第 1 段階よりも大きなリスクを 抱えていることに注意しなくてはならない。当 事者による慎重な検討と併せて、その推移に対 して今以上に社会的な注視と発言を強めていく ことが求められているのである。

そして、次に迎えるのが第1段階での導入館が 2 巡目へと進む第3段階（平成20２2年頃）であ る。そこで、この制度を暴走や迷走させないた めに関係者への提言と注視すべき要点を示して おく。

\section{(1)公立博物館のあり方から}

立脚点の一つとして「公立博物館の設置及び 運営上の望ましい基準」(平成15年6月6日文部 科学省告示) がある。例えば、第 4 条「資料を展 示するに当たっては」に「確実な情報及び研究 に基づく正確な資料を用いる」と示されている。 これにより、公立博物館の利用者へのサービス
とは「正確で詳細な資料と情報」(信頼性)を 「誰でもが使えるよう分かりやすい形で提供す る」(公平性)にあり、これを実現できる選択や 条件設定がなされなくてはならない。

(2)博物館の本来業務・社会的機能から

高い専門性をもつ博物館がその役割を果たす には、「同一事業者が、適切な期間、安定した条 件の下で業務に取り組める運営体制」が必要で ある。現状では、指定管理の期間はほとんどの 場合、特段の根拠もないまま 3 年が選択され ている。このような短い期間の繰り返しでは、 本来業務である「資料の保存・継承と公開・活 用」、専門職員 (学芸員) の確保と人材育成」を 危うくし、公共施設としての信頼性さらに経済 効率の上でも合理性に久ける。指定期間は、博 物館の業務と機能の特性を尊重して選定されな くてはならない。

\section{(3)博物館が対象とする資料から}

博物館が住民の負託に応え、利用者に質の高 いサービスを提供するには既に公開されている 資料だけでなく、収蔵されている資料全体や未 だ地域に埋もれている資料も視野に入れた、「所 在調查一収集一調查研究一整理一保存」の一連 の活動が不可欠である。経済効率を優先し、利 用料金収入を増大させる事業に重点が置かれる 結果、こうした基盤業務が踈かにされることが あってはならない。

\section{おわりに}

現状とそこでの問題の要点を述べてきたが、 「さまよえる公立博物館」への処方箋は関係者一 
同が「博物館が住民や利用者に提供する質の高 いサービスとは何か」を、設置目的に立ち返っ て再確認することにあると言ってよい。その具 体的方策として、次のことを提言しておく。

（1）設置者は、設置目的に適した運営方法（直 営・指定管理者制度・地方独立行政法人 $<$ 大阪市が検討＞など）を選択する。

（2）設置者が設定する管理の基準と経費は、博 物館の設置目的に則ったものとする。応募 者は、設置目的や施設の実態から逸脱した 内容の提案は控える。

（3）設置者は指定の期間として、10年（既存館） ～15年 (新設館)を目安とする。 5 年每に業 績審查を行って継続か否かを判断する。

（4）設置者は、独自の評価制度<例：横浜市の 特定協約団体制度 $>$ や審査を経た団体等の 単独選定も考慮する。団体等はJV方式を含 む合理的な運営形態を提示し、設置者は管
理の基準による事業評価や他制度による監 察を行う。

それでもな技処方嘎を見つけ出すことができ ないならば、この制度は本質的に公立博物館運 営には適さないとの観点から再検討を行う必要 がある。

\section{『学術の動向』 平成19月3月号以降の特集テーマ (予定)}

『学術の動向』では、今後の各号の特集テーマを 以下のように予定しておりますので、ご期待ください。

平成19年 3 月号 「歴史としての戦後·思想としての戦後」

4月号「人文社会科学の役割と責任」(仮題)

5月号「「医療を崩壊させないために」(仮題) 